\title{
Falling Oil Price, Exchange Rate Volatility and Marco- economic Variables in Nigeria
}

\author{
Olure Bank Adeyinka Michael ${ }^{1}$, Gbadebo Salako ${ }^{2}$, Ajiteru Temilade ${ }^{2}$ \\ ${ }^{1}$ Department of Economic, Joseph Ayo Babalola University, Ikeji-Arakeji, Osun State \\ ${ }^{2}$ Department of Economic, Emmanuel Alayande College of Education, Oyo, Oyo State, Nigeria
}

Email address:

adeyinka67@gmail.com (O. B. A. Michael),gbadebosalako@gmail.com (G. Salako)

\section{To cite this article:}

Olure Bank Adeyinka Michael, Gbadebo Salako, Ajiteru Temilade. Falling Oil Price, Exchange Rate Volatility and Marco-economic

Variables in Nigeria. Journal of Investment and Management. Vol. 4, No. 1, 2015, pp. 25-33. doi: 10.11648/j.jim.20150401.14

\begin{abstract}
With the oil price at low level in Nigeria, exchange rate volatility has been manifested at different exchange rate regimes in Nigeria, the study look at the relationship between exchange rate volatility and Macroeconomics variables in Nigeria between 1985-2014. Secondary data were collected from Central Bank Statistical Bulletin, employing Johansen Error Correction Model (ECM) Technique to estimate the collected time-series data and General Conditional Heteroskedasticity $(\mathrm{GARCH})$ to measure volatility. It is therefore observed and recommended that the Nigeria government should employ greater policy sensitivity towards the openness of the economy so that the capital flows that come through foreign direct investment (FDI) will be beneficial to the economy as a whole.
\end{abstract}

Keywords: Exchange Rate, Foreign Direct Investment, Economic Growth, Marco-economic Variable

\section{Introduction}

In recent time, one striking feature of the world economy is the growth of Foreign Direct Investment (FDI) and the market for it has become more competitive. Developing countries are becoming increasingly attractive as investment destinations because they can offer investors a range of "created" assets (World Bank 2003). This attractiveness not withstanding investors must also consider the effect of fluctuations in the exchange rate because exchange rate fluctuations hurt producers and investors alike as it affect their planned revenue and costs, including profit margin. Instability in the exchange rate may distort the realisations of such estimates. For example, exchange rate depreciation result in high cost importing raw material and capital goods. The effect of exchange rate volatility on macroeconomics variables performances has continued to generate interest among economists.

FDI is essential for growth and development in Nigeria. In fact, it is argued that low and volatile FDI is part of the challenges to the persistent poverty, high inequality and underdevelopment of Nigeria economic because Nigeria manufacturing sector is highly depending on the importation for it inputs and capital goods. These imported inputs and capital goods are paid for in foreign exchange, which is not stable. Thus, the variations in exchange rates are bound to adversely affect activities in the sector that is dependent on external sources for productive inputs.

The exchange rate situation in Nigeria has been plagued by various problems in the recent time some of which are instability in price of naira, balances of payment, low level of competition due to falling of oil price. The importance of foreign capital inflows to Nigeria is generally perceived as something desirable.

The structural adjustment programme (SAP) which was introduced in july, 1986 led to the adoption of floating exchange rate in Nigeria and devaluation of the Nigeria naira. A cardinal objective of the SAP was the restructuring of the production sectors of with a positive bias for the production of agricultural exports is shown. The foreign exchange reforms that facilitated a cumulative depreciation of the effective exchange rate were expected to increase the domestic prices of agricultural exports and therefore boost domestic production and the regulation of the foreign exchange market aim at improvement of market determined exchange rate, managed floating exchange rate regime. The Central Bank of Nigeria usually intervenes in foreign exchange market through its monetary policy actions and operations in the money market to influence the exchange rate movement in the desired direction such that it ensures the competitiveness of the domestic economy. The 
introduction of managed floating exchange rate regime tends to increase the uncertainty in exchange rate, thus, increasing the volatility of exchange rate by regime shift. This make the exchange rate to be the most important asset price in the economy. The understanding of exchange rate behaviour is important to the monetary policy ( Longmore and Robinson, 2004). Also SAP was aim to develop other export sector of the economy with the goal of diversifying the economy from it dependence on oil Trade, and liberalisation of the economy. However, these policy have analytical support in the counter revolutionary paradigm of Bretton wood school. One of the paradigm propositions is low level of non-oil exports particularly agriculture is caused by exchange rate overvaluation, agricultural taxes, and marketing board profits. Nigeria CBN exchange rate policy has been aimed at preserving the external value of the domestic currency and maintaining a healthy balance of payment position, which, indeed, is a major provision of enabling law. With failure of the Autonomous Foreign Exchange Market (AFEM) in 1995, an Inter-bank Foreign Exchange Market (IFEM) was introduce in 1999 designed as a two way quote system, and intended to diversify the foreign exchange in the economy by encouraging the funding of the inter-bank operations from privately earned foreign exchange. The IFEM is to assist the naira to achieve a realistic exchange rate. The IFEM experienced similar problem and setback as the AFEM, owing to supply side rigidities, the persistent expansionary fiscal policy operations of the government and the attendant problem of persistent excess liquidity in the system.

\subsection{Overview of Nigeria Oil Sector}

Nigeria is Africa's top oil exporter, and the world's tenth largest oil producing country. It has realized over US\$ 600 billion in oil revenues since 1960, a figure greater than the resources used by the Marshall Plan in rebuilding Europe after World War Two and is currently the 8th highest net oil exporter in the world. Nigeria's economy is heavily dependent on natural resources: oil and gas constitutes circa 80 percent or more of government revenues in some years. The 1970's ushered Nigeria into a new era of prosperity, enjoying a bounteous oil windfall due to the increase in global oil prices precipitated by the Arab Israeli crisis. The negative effects of this oil windfall were reflected in exchange rate appreciation, import subsidies, and a decline in vital sectors such as Agriculture and manufacturing in the case of Nigeria, the solid mineral sector also suffered as earlier pointed out. However, the profligacy and waste that accompanied Nigeria's elevation to the status of an oil-rich petro state experienced a hitch at the start of the next decade. The 1980's oil glut forced a sharp drop in oil receipts, and consequently economic growth. Confronted with corruption, capital flight and mounting foreign debt, Nigeria, was left with no option but to undergo structural reforms such as the IMF's Structural Adjustment Programmes (SAP) to address the distortions caused by oil dependence. With the return to democratic rule in 1999, a series of macroeconomic and fiscal reforms have been undertaken, most of them having economic diversification as a core element. It was also able to secure a debt buy back deal from the Paris club in 2006 which reduced the external debt even though her current domestic debt of circa $\$ 34$ billion is a threshold that is perturbing.

\subsection{Significances of the Study}

The need to understand the relationship between exchange rate volatility and macroeconomics variables in Nigeria economy is a long time debate. This study is premised on identifying the causes and the consequence of exchange rate volatility on macroeconomics variables with foreign direct investment in Nigeria as is main focus. Foreign direct investment is viewed as major stimulus to economic growth in developing country like Nigeria. It ability to deal with three major problem namely shortages of financial resources, technology and skill labour has made it the centre of attention for the policy maker in low income countries. Despite good performance of FDI, it is characterised by considerable fluctuations over time which phenomenon according to Fucei and boreli (2008) is attributed to exchange rate volatility. Exchange rate volatility is being increasingly recognised as a disincentive to Nigeria as FDI destination (Ogunleye 2008). with all above this study seek to establish how the various exchange rate regime do affects foreign direct investment and other macroeconomics variables in Nigeria.

\subsection{Scope and Limitation of Study}

The totality of exchange rate volatility and macroeconomics variables in Nigeria are the focus of the study. The study investigates empirically the relationship exchange rate volatility and macroeconomics variables also the variable that effects foreign direct investment in Nigeria. The study use a time series data of 29 years spanning from 1985-2014, collated from secondary sources to include Central Bank of Nigeria (CBN) Statistical Bulletin, Annual report, Statement of Account of various issues.

\subsection{Outline of the Study}

The study is divided into five part, part one introduce the subject matter of the study, statement of the problem, significances of the study, scope and limitation of the study and outline of the study. Part two, discusses the theoretical and empirical reviews of literature, showing the concept of exchange rate volatility and foreign direct investment in Nigeria. Part three presents theoretical framework, methodology, estimation technique, model specification, and measurement. Part four, have result and discussion of result of findings. While part five talk on summary, conclusion and recommendation.

\section{Empirical Review of Literature}

Many related empirical studies conducted on some developing countries shows the effect of Exchange Rate Volatility on Foreign Direct Investment (Schuh, 1974; 
Ihimodu. 1993; Ogiogio, 1993; Obadan, 1994). In some cases, domestic demand deficiencies are important reasons for a home country to invest in a foreign market. In such situations, the home country's GDP could be negatively related to FDI (Pitelis 1996).

Per capital GDP measures labour productivity and it is expected that high labour productivity encourages FDI. It is also assumed that higher wage rates discourage inward FDI, so the expected sign for the coefficient could either be positive or negative. Thomas and Grosse (2001) reported the negative relationship of GDP and inward FDI to Mexico during the period from 1930-1995 using the general least squares (GLS) method. Brozozowski 2006 studied FDI flows from the European Union (EU) into Mexico for the period from 1994 to 1997. Their results suggest that GDP and real per capita GDP are negative. Pan (2003) studied inward FDI in china during 1984 In 1996 and found a significant but negative relationship. The above literature indicates that inward FDI into a developing country does not hold in the same way as it does for a developed country.

One factor that can adversely impact investor profit is the rate of inflation. Normally, it assumed that the higher the price is for an item the greater the profit will be but a high inflation rate can be viewed as a barrier to FDI. Botric and Skuflic (2006) examined the determinant of FDI in countries in southern Europe from 1996 to 2002 and found that FDI had a positive but insignificant effect on inflation.

In contrast, Trevino et al, 2002 studied FDI flows in Latin America and reported that FDI flows had a negative but insignificant effect on inflation. Cushman (1985,1988).

Unlike the studies reviewed above, the negative impact of exchange rate volatility on FDI was measured by the coefficient of variation of quarterly nominal exchange rate over the past three years, on FDI from developed to developing countries for the 1984-96 period by using annual data. They found that high exchange rate volatility discouraged FDI while the depreciation of local currency promoted FDI from developed countries. Urata and Kawai (2000) included exchange rates and their volatility, which was measured by the coefficient of variation of exchange rate over five-year period, in their study of Japanese firm's decision on the location choice. By analysing a firms level panel data covering 1980-94 for 117 countries from four manufacturing industries in Japan, they also found that high exchange rate volatility discouraged FDI while the depreciation of host country's currency increased Japanese FDI to those countries.

\subsection{Theories of Exchange Rate Determination}

The exchange rate theories are classified into three which are; Partial, general and disequilibrium models.

Partial Equilibrium Models: include relative purchasing power parity and absolute power parity,which only consider the goods market; and covered interest rate parity(CIRP) and uncovered interest rate parity (UCIRP), which only considers the assets market, and the external equilibrium model, which states that the exchange rate is determined by the balance of payments.

General Equilibrium Models: impact of volatility on FDI has been within a partial equilibrium framework, that is, the only variable that changes in some measure of the variability of exchange rate, and all other factors that influence on the level of FDI are assumed to remain unchanged. However, those developments that are generating the exchange rate movements are likely to affect other aspects of economic environment which will in turn have an effect on FDI flows. Thus it is important to take an account in a general equilibrium framework the interaction of all the major macroeconomic variables to get a more complete picture of the relationship between exchange rate volatility and FDI.Such an analysis has recently been provided by Bacchetta and Van Wincoop (2010). They develop a simple, two country, general equilibrium model where uncertainty arises from monetary, fiscal and technology shocks, and they compare the level of trade and welfare for fixed and floating exchange rate arrangements. They reach two main conclusions. firstly, there is no clear relationship between the level of FDI and the type of exchange rate arrangement, a monetary expansion in the foreign country would depreciate its exchange rate, causing its to reduce its import but the increasing demand generated by the monetary expansion would offset part of the exchange rate effect. Thus, the nature of the stock that causes the exchange rate change can lead to changes in other macroeconomic variables that offset the impact of the movement in the exchange rate.

\subsubsection{Concepts and Definition of Exchange Rate Volatility}

To stimulate an understanding of exchange rate volatility and Foreign Direct Investment in Nigeria, it is important to define the key concepts that are central to the study. Exchange rate refers to the rate at which one currency exchange for another (Chingan, 2003). Exchange rate is said to depreciate if the amount of domestic currency required to buy a foreign currency increases, while the exchange rate appreciates if the amount of domestic currency required in buying a foreign currency reduces. An appreciation in the real exchange rate may create current account problems because it leads to overvaluation. Overvaluation in turns makes imports artificially cheaper while exports relatively expensive, thus reducing the international competitiveness of the domestic country (Takaendesa, 2006). However exchange rate can be expressed in one of two ways; as unit of domestic currency per unit of foreign currency, as unit of foreign currency per Domestic currency (Charles, 2006). It is a very important price in which the government alikes very active interest (Obadan, 2006). However two concept of exchange rate are commonly distinguished: nominal exchange and real exchange rates. The nominal exchange rate (NER) is a monetary concept which measures the relative prices of two currencies e.g. Naira in relation to US Dollar. But the real exchange rate (RER), as the name implies is a real concept that measures the relative prices of two goods-tradable goods (export and import) in relation to non tradable goods (goods and services produced and consumed locally). 
Exchange rate volatility refers to the swings or fluctuations in the exchange rates over a period of time or the deviations from a benchmark or equilibrium exchange rate (Mordi, 1006).

\subsubsection{Concepts and Definition of Foreign Direct Investment}

Foreign direct investment is that investment which is made to serve the business interest of the investor in a company, which is in a different nation distinct from the investor's country of origin.

According to Kyereboah and Kwame (2008) foreign direct investment is an investment that involves a long term relationship between a foreign investor or parent enterprise or an affiliate enterprise. They further point out that the FDI concept only holds if the investor has a significant degree of influence on the management of the enterprise resident in the other economy. This investment involves both the initial transaction between the two entities and subsequent transactions between them and among foreign affiliates; both incorporated and unincorporated. Economy watch (2008), stresses that the relationship between the resident company and the foreign affiliate qualifies as a FDI if the parent enterprise through its direct investment effort exercises substantial control over the foreign affiliate company. "Control" in this case is the ownership of the greater than or equal to $10 \%$ of ordinary shares or access to voting rights in an incorporated firm and an equivalent criterion for an unincorporated firm can be consider. Otherwise, ownership share amounting to less than that $10 \%$ is termed as portfolio investment and is not categorised as FDI. Theories that are related to the types of FDI suggests that there are two types of FDI, while some other theories suggests four types of FDI, which include Horizontal (market-seeking), Vertical, In-ward and Out-ward FDI.

\subsection{Exchange Rate Vitality and Foreign Direct Investment}

There are several arguments concerning the mechanism by which currency exchange rate volatility affect FDI. These arguments relate to the difference types of multinational activities undertaken in a particular location, the destination of the finished goods or service produced and the sources of intermediate inputs. For example, Kiyota and Urata (2004) find that real exchange rates play an influential role for the locational determinants of the FDI of Japanese firms in aggregated and disaggregated industries. Kimino, Saal and Driffield (2007) in their attempt to model Japanese FDI inflows pointed out that the exchange rate differences could have been responsible for the changes in the "marketing seeking" FDI only that they related this argument to FDI flows between developed economies following from Markusen (1998) and Dunning (1993), who suggested that most FDI occurs between high income developed countries where firms are looking to either expand into markets similar to their own or protect their home market from foreign competition. This observation can also extend to FDI flows to low income countries, an example is the current influx of telecommunication companies into Nigeria whose major motivation is mainly "market seeking".

According to Benassy-Quere et al (2001), appreciation of the home currency reduces the cost of capital, enabling firms to invest more easily abroad relative to firms in countries with a depreciated currency. Conversely when MNRs uses the local market as an export platform, then FDI and trade will become compliments.

Froot and Stein (1991) find that depreciation of the host currency leads to larger FDI inflows. They argue that appreciation of the source country currency relative to that of the host currency increases the wealth position of firm reducing the relative cost of capital and allowing them to invest more actively in the foreign market.

Compared with the studies analysing the effects of exchange rate and other variables, there are only few studies that empirically examined the impact of exchange rate volatility on FDI.

\subsection{Sources of Real Exchange Movement}

In analysing the impacts of real exchange rate volatility on FDI, one should be concerned with the sources of real exchange rate movements. Recent empirical studies suggest that the behaviour of real exchange rate is attributed to the failure of establishing the law of one price (Engel (1993, 1999) and Rogers and Jenkins (1995)). Indeed, these studies found that the distance and the border played important roles in the failure of establishing the law of one price, which in turn becomes part of the source of real exchange rate movements (Engel and Rogers (1996). Engel and Rogers (1996) tested two hypotheses: (1) the volatility of the prices of similar goods between cities should be positively related to the distance between those cities because of the geographical separation of the markets in determining the degree of the failures of law of one price and (2) the volatility should be higher between two cities separated by the national border holding the distance constant. Using the price data of the United States and Canada, their regression analysis confirmed the validity of these two hypotheses: both the distance and the national border were important in explaining the price dispersion between cities when exchange rate is flexible.

\section{Model Specification}

The model employed in this study takes a lead from the works of Alaba (2003) and Russ (2007) with minor modifications made in Ibrahim and Omoniyi

$$
\mathrm{FDI}=(\mathrm{GDP}, \mathrm{OPN}, \mathrm{WOP}, \mathrm{EXR}, \mathrm{INF}, \mathrm{WOP}, \mathrm{EXRV})
$$

The econometrics representation of the model is:

$\mathrm{GDP}=\beta_{0}+\beta \mathrm{iBOP}+\beta_{2} \mathrm{WOP}+\beta_{3} \mathrm{FDI}+\beta_{4} \mathrm{INF}+\beta_{5} \mathrm{EXRV}+\mathrm{n}$

Where:

$\mathrm{GDP}=$ Gross Domestic product

$\mathrm{BOP}=$ Balance of Payments 
WOP $=$ World Oil Price

FDI $=$ Foreign Direct Investment

$\mathrm{INF}=$ Inflation rate

$\mathrm{EXRV}=$ Exchange Rate Volatility

$\mu=$ Stochastic error term

$\beta_{0}=$ Constant term

$\beta_{1}-\beta_{\mathrm{s}}=$ Estimated parameters

Apriori Expectation

Based on economic theory, the following a-priori relationships are postulated for the estimated results. $B_{1}>0 \beta_{2}>0$ $\beta_{3}>0 \beta<0 \beta_{5}<0$

\subsection{Estimation Techniques}

The estimation techniques used to estimate and interpret the econometric and empirical investigation subsisting between endogenous variables using Johansen Error Correction Model (ECM) technique to capture the white noise embedded in the secondary data employed error in the model. The generalised auto-regression conditionally heteroskedastic $(\mathrm{GARCH})$ was used to measure the volatility. The model is later re-specified to get a true picture of the event that taken place between the variables by introducing stationarity-unit root test, co-integration and error correction model. Also, the coefficient of determination is estimated to know the percentage of total variation on the dependent variable explained by the independent variable. The higher the co-efficient of determination the more useful the model will be for policy and predictive purposes. The F - statistics helps to determine whether or not all the partial regression co-efficient is equal to zero. An evaluation of the model equation on these criteria further supports the significance of the explanatory variable. To this end, in order to avoid spurious regression, the study carried out the following additional test:

\subsubsection{Unit Root Test}

To test the unit root using the DF test, we proceed by estimating the model

$$
\mathrm{Y}_{\mathrm{t}}+\mathrm{Y}_{\mathrm{t}-1}=\mathrm{Et}
$$

Equation (3) is rewritten as

$$
\mathrm{Yt}=\mathrm{aY}_{\mathrm{t}-1^{-}},-\mathrm{Y}_{\mathrm{t}-1},+\mathrm{Et}
$$

Equation (4) is rewritten as

$$
\mathrm{Yt}=(\mathrm{a}-\mathrm{l}) \mathrm{Y}_{\mathrm{t}-1}+\mathrm{Et}
$$

Solving equation (5) where $(\mathrm{a}-1)=\varnothing$ we have

$$
\mathrm{Yt}=0 \mathrm{Y}_{\mathrm{t}-1}+\mathrm{Et}
$$

If $\mathrm{p}<1$ then $\theta<1$, then $\mathrm{Yt}$ is stationary and it is integrated of order zero i.e. $1_{(0)}$.

Augmented Dickney - Fuller (ADF) Unit root was employed to determine the other of each time series.

\subsubsection{Co-integration Technique}

Two variables e.g. $\mathrm{Ct}$ and $\mathrm{Yt}$ are co-integrated if they satisfy the order of integration for the level and the differenced data series.

Then the residuals from the static equation of the variables in their level form are generated. After this, we use ADF Test to determine whether or not the residual $\mathrm{Ct}$ is $1_{(0)}$ i.e. are stationary. If the residual are of $1_{(0)}$, then the conclusion is that the equation under scrutiny is cointegrated.

In the event of non-stationary in the series tests, the implication behind this series of tests is that each time series is non-stationary linear combinations of such time series that are stationary might that the long-run movements in these multiple time series are related to each other. Indeed, if there is a long run relationship between two or more nonstationary variables, then the idea of the general concept of co-integration is that deviation from this long-run path are stationary.

\subsection{Error Correction Model}

The residuals generated from the static regression are called the error correction term. The error correction issue boil down to using the error term so derived to reparameterise the short-run dynamic specification. When this is done, we obtain the error correction model as:

$$
\mathrm{Ct}=\beta_{0}+\beta_{1} \mathrm{Yt}+\Delta \beta_{2} \mathrm{et}+\mathrm{Vt}
$$

Here a plays the role of an error correction co-efficient and it should be less than 1. Since adjustment is not fully realised. The starting point of ECM is a test against the null hypothesis that the residuals of the long run (static) model are non-stationary. Here we apply both the ADF and DF tests to the residuals of the static co-integrating regressions. The evidence of the stationary of the residuals indicates that the variable in the models are indeed cointegrated. Adopting Engle - Granger representation is ECM, we employ an error correction dynamic specification dynamic specification of the form:

$$
\mathrm{GDP}=\beta_{0}+\beta_{1}, \mathrm{~L}(\mathrm{Z})-\beta_{2} \mathrm{EC} \mathrm{t}_{-}+f t
$$

Where $\mathrm{Z}$ is the vector variable that co-integrate with the gross domestic product $\mathrm{L}$ is a general lag operator.

Between the level of inflation and the level of one or more of its determinants are permitted to affect the current change in inflation. Equation (6) can be reduced to a parsimonious equation through the elimination of insignificant terms and the imposition of constraints that hold a reasonable approximation.

Generalised Auto-regression Conditionality Heteroskedastic: it also employed multivariate GARCH model to analyse the exchange rate volatility transmission among the estimated variables. GARCH models, the most popular for time varying estimation, was initially introduced by Engle (1986: 987-1008) and consequently extended by many economist like Bollerslev (1986: 308-326), Bollerslev (1990: 498-505), Bollerslev and Engle (1993: 167-186), Engle (2001: 167-168), Bera and Kim (2002: 171-195). Multivariate GARCH models have also been used to investigate volatility and 
correlation transmission and spill-over effects in studies of cointagion. It includes both its own conditional variance and covariance.

General Autoregressive Conditional Heteroskedastistic Model (GARCH) differs to the ARCH model in that it incorporates squared conditional variance terms as additional explanatory variables. This allows the conditional variance to follow an ARMA process. If we write the residual as T-statistics and the usual diagnostic tests could also be added to this model. If there was only the one lag on the $h$ variable, we could have a GARCH process which is the same as an ARCH process. The main problem with an $\mathrm{ARCH}$ model is that it requires a large number of lags to catch the nature of the volatility; this can be problematic as it is difficult to decide how many lags to include and produces a non-parsimonious model where the non-negativity constraint could be failed. The GARCH model is usually much more parsimonious and often a GARCH model is sufficient, this is because the GARCH model incorporates much of the information that a much larger ARCH model with large numbers of lags would contain.

\section{Unit Root Test Result}

The Augmented Dickey - Fuller (ADF) unit root test shows that inflation rate (INF) and exchange rate volatility (EXRV) are stationary at all level, that is they are integrated of order zero $\mathrm{I}_{(0)}$, while foreign direct investment (FDI), degree of trade openness (OPN), exchange rate (EXR), and World oil price (WOP) are stationary at the first difference and this implies that they are integrated of order one $1_{(1)}$, However, the result shows that Gross domestic product (GDP) is stationary at the second difference and this also implies that it is integrated of order two $1_{(2)}$

\subsection{Analysis of ARCH and GARCII (Autoregressive Conditional Heteroskedasticity and Generalised Conditional Heteroskedasticity)}

Autoregressive Conditional Heteroskedasticity (ARCH) models are specifically designed to model and forecast conditional variances. The variance of the dependent variable is modelled as a function of past values of the dependent variable and independent or exogenous variables.

Decision Rule:

The decision rule below is based on the rule of the thumb and cited by Yinusa (2004)

If $\alpha+\beta<1$ No volatility

If $\alpha+\beta \rightarrow 1$ There is Volatility

If $\alpha+\beta>1$ This is the case of overshooting, meaning an outrageous level of volatility

Note: $\alpha=\mathrm{ARCH}$ term/coefficient, while $\mathrm{p}=\mathrm{GARCH}$ term/coefficient

From the result of $\mathrm{ARCH}$ and $\mathrm{GARCH}$, it revealed ARCH coefficient of 1.227374 and GARCH coefficient of - 0.157777. The summation of the ARCH and GARCH coefficient equals 1.069597. Therefore, since $\alpha+\beta>1$, i.e. $(1.069597>1)$, we can conclude that there is a case of overshooting, which implies an outrageous level of volatility, i.e. the variables exhibit element of volatility clustering.

The Short Run Relationship between Exchange Rate Volatility and Foreign Direct Investment, Using Ordinary Least Square (OLS). Substituted coefficients:

$$
\begin{gathered}
\mathrm{FDI}=-969294.3+3.576131 \mathrm{GDP}+35798.71 \mathrm{OPN}- \\
8110.553 \mathrm{EXR}-762.6544 \mathrm{INF}+8156.657 \mathrm{WOP}+ \\
12531.99 \mathrm{EXRV}
\end{gathered}
$$

From the regression equation specified above, it revealed a constant value of - 969294.3 and this represent the value of foreign direct investment (FDI) in Nigeria if all the explanatory variables in the model are held constant. The equation further revealed that EXR and INF have a negative relationship with FDI, as a unit increase in EXR and INF will reduce the FDI by 8110.553 and 762.6544 respectively in the short run. However, the result revealed that exchange rate volatility (EXRV) has a positive impact on the FD]. It revealed that a unit increase in the EXRV increases the FDI by 12531.99 within the period under review. Similarly, the result shows that GDP, OPN and WOP have a positive impact on FDI and this implies that a unit increase in them will increase the FDI by 12531.99, 35798.71 and 8156.657 respectively.

The result also revealed an R-square of about 0.879363 and this implies that about $88 \%$ of the systematic variations in the FDI is being explained by the variations in the explanatory variables. This shows that the model is a good fit as only about $12 \%$ of the variations are not accounted for by the model and this is attributed to the error term.

The result of the Trace test present 5 co integrating equation(s) at the 0.05 level since the trace statistic is greater than critical value at $5 \%$.

The result of the maximum eigen value test indicates two (2) co integrating equations at $5 \%$ critical value. However, according to Johansen and Juselius (1996) recommends the use of the trace statistics when there is a conflict between the maximum Eigen value and the trace statistics.

Hence, the long run relationship among the variables will then be determined by the normalised co-integrating coefficient with the highest log likelihood in absolute term. The result Log likelihood is -962.6920

From the result the co integrating equation is specified thus:

FDI- 1.045741 GDP $\mathrm{G}_{\mathrm{t}-1}-98340.37 \mathrm{OPN}_{\mathrm{t}-1}+18757.31 \mathrm{EXR}_{\mathrm{t}-1}-$ 19117.08INF $\mathrm{IN}-1-38221.19 \mathrm{WOP}_{\mathrm{t}-1}+322177.8 \mathrm{EXRV}_{\mathrm{t}-1}$

The above equation represents the normalised co integrating equation with the highest log likelihood in absolute terms. From the above equation, it revealed that gross domestic product (GDP), exchange rate (EXR) and exchange rate volatility (EXRV) have a long run positive 
relationship with the foreign direct investment (FDI) and this implies that a unit increase in the GDP, EXR and EXRV will increase the FDI by $1.045741,18757.31$ and 322177.8 respectively in the long run. This result conforms to the apriori expectation earlier stated in the previous chapter of the study as it reveals a positive relationship between gross domestic product (GDP) which is the major indicator of the country's economic performance and the foreign direct investment. This result shows that an increase in the rate of country's domestic economic performance will attract foreign investors in the long run as they will be induced to invest in the economy. However, the result shows that degree of trade openness (OPN), inflation rate (INF) and world oil price (WOP) have a negative long run relationship with foreign direct investment (FDI) in Nigeria throughout the period under review. This implies that a unit increase in the OPN, INF and WOP will reduce the FDI by 98340.37 , 19117.08 and 38221.19 respectively in the long run.

The Error Correction Model (ECM) integrates the long-run equilibrium relationship with short run dynamics. The ECM involves two stages. The overparameterized Error Correction Model (ECMi) and the Parsimonious Error Correction Model

R-squared 0.812457

Adjusted R-squared 0.573765

Durbin - Watson stat 2.040760

prob (F- statistic) 0.023842

F - statistic 3.403791

It shows the initial overparametersed ECM] model. All the variables were lagged equally by one period. Since only four variables are significant at 5 percent level significance, there is therefore the need to proceed on the parsimonious Error Model (ECM2).

Parsimonious error correction model (ECM2)

R-squared 0.710950

Adjusted R-squared 0.582483

Durbin-Watson stat 1.966465

F-statistic 5.534117

Prob( F-statistic) 0.00126

The results of the parsimonious Error Correction Model.

The equation of the ECM is therefore specified in line with parsimonious model as follows:

$$
\begin{gathered}
\text { FD1 }=6186.506-0.152310 \text { FDIt-1+ } 0.125527 \mathrm{GDPt}-1+ \\
\text { 5424.624OPNt-1 -7801.809EXRt }-1-726.8518 \mathrm{INFt}-1 \\
+ \text { 5050J44WOPt. } 1+26766.58 \text { EXRVt-1, }-0.979078 \mathrm{ECMt}-1
\end{gathered}
$$

The equation above shows an ECM value of- 0.979078 which is otherwise referred to as the speed of adjustment. The speed of adjustment is significant at 5\% considering its probability value $(0.0001 \%<5 \%)$ and standard error. Also, the ECM is correctly signed which implies that about $98 \%$ of the short-run inconsistencies are being corrected and incorporated rated into the long-run relationship. The implication of this is that the present value of FDI will adjust to changes in GDP,OPN, EXR, INF, WOP and EXRV. The $\mathrm{R}^{2}$ of about 0.710950 implies that about $72 \%$ of the dynamic variation in FDI is being explained by variations in GDP,
OPN, EXR, INF, WOP and EXRV. This shows a very good fit of the model as only about $28 \%$ variation unaccounted for by the model is r:'-.r.ed to the error term. From the ECMa equation, the present value of FDI has a negative relationship with the previous value of FDJ. This implies that foreign direct investment does not obey the time series property that the past value of a variable should exert positively on the present value of the variable. Also from the equation, it revealed a constant value of 6186.506 which represents the value of the foreign direct investment, if all he explanatory variables in the model are held constant. Also, it revealed that gross domestic product (GDP), degree of trade openness (OPN). World oil price (WOP) and the exchange rate volatility (EXRV) have a positive relationship with the foreign direct investment (FDI) in Nigeria and this implies that a unit increase in GDP, OPN, WOP and EXRV will increase the FDI by $0.125527,5424.624$. 5050.244 and 26766.58 respectively. However, the equation further revealed that exchange rate (EXR) and inflation rate (INF) has a negative relationship with the foreign direct investment (FDI), this implies that a unit increase in EXR and INF will reduce the FDI by 7801.809 and 726.8518 respectively. The analysis of the Durbin-Watson test for autocorrelation reveals that the model is free from first-order serial autocorrelation. This implies that the model is well specified.

\subsection{Discussion of Findings}

It revealed through the unit root test that gross domestic product (GDP) is stationary at the second difference which implies that GDP can sustain any form of shock passed on it for a long period of time. However, the result of the unit root test further shows that INF and EXRV are integrated of order zero and this also indicates that INF and EXRV cannot sustain any form of shock passed on them. Furthermore, FDI, OPN, EXR and WOP are all integrated of order one and this implies that they can only sustain any form of shock passed on them for a short period of time. Also, the result of the co integration test shows that OPN. IYOP and INF are the only variable having a long run negative relationship with FDI in Nigeria, while GDP, EXR and EXRV contributes positively in the long run to FDI. The equation of the error correction mechanism (ECM) reveals an ECM coefficient which is also the speed of convergence of about, -0.979078 which implies that $98 \%$ of the short run inconsistencies are being corrected. While the equation further revealed that EXR. and INF have a negative relationship with foreign direct investment in Nigeria, while all other variables, (GDP, OPN, WOP and EXRV) exerts a positive impact on FDI in Nigeria. Though none of the variables passed the test of significance on FDI except exchange rate (FiXR) which has a positive significant impact on foreign direct investment (FDI) in Nigeria.

\section{Summary and Recommendation}

From analysis of the empirical results, the result of $\mathrm{ARCH}$ and GARCH. the summation of the ARCH and GARCH term is greater than one i.e. $(1.069597>1)$, it was concluded that 
there is a case of overshooting, which implies an outrageous level of volatility, i.e. the variables exhibit element of volatility clustering. Also, the result of the co integration test shows that OPN, WOP and INF are the only variable having a long run negative relationship with FDI in Nigeria, while GDP, EXR and EXRV contributes positively in the long run to FDI. The equation of the error correction mechanism (ECM) reveals an ECM coefficient which is also the speed of convergence of about -0.979078 which implies that $98 \%$ of the short run inconsistencies are being corrected. While the equation further revealed that EXR and INF have a negative relationship with foreign direct investment in Nigeria, while all other variables, (GDP, OPN, WOP and EXRV) exerts a positive impact on FDI in Nigeria.

Also, from the result established by the co integration test, we can conclude that gross domestic product, exchange rate and exchange rate volatility are positive determinant of foreign direct investment in Nigeria. This conclusion could be attributed to the role of GDP in the economy as it reveals the performance of an economy, therefore, foreign investors may be attracted to invest in such an economy that witness a persistent increase in her GDP. Likewise the exchange rate volatility, foreign investors will be very conscious about the current fluctuations in price of the local currency of their preferred country at the foreign exchange market. The analysis of the short run relationship in the model revealed an $\mathrm{R}^{2}$ of about $0.879363(88 \%)$, from this result, it can be concluded that GDP OPN EXR INF WOP and EXRV can explain about $88 \%$ of the variations in Nigeria's foreign direct investment.

\section{Recommendations}

In the light of the above findings, the following recommendations are made: First, the government should ensure that the profits realised by the Multinational cooperation who supplies Foreign Direct Investment in terms of capital flows should be encouraged to reinvest major parts of their profits into the Nigerian Economy. One way to improve the business environment is by conscious provision of necessary infrastructure which will lower the costs of doing business in Nigeria.

The federal government should ensure that a clean floating rate policy is adopted so as to be able to determine the real status of the Nigerian naira rather than operating a dirty floating exchange rate where the naira exchange is allowed to float between a bound of ( + or -$) 5$ percent. If the clean floating exchange rate policy is adopted, it will encourage trade liberalisation rather than engaging on devaluation/revaluation of the Nigerian naira to encourage trade liberalisation.

\section{References}

[1] Benassy-Quere, A. Fontagne And Lahreche-Revil, A. 2001; Exchange Rate Strategies In The For Attracting Foreign Direct Investment. Journal Of The Japanese International Economics, Vol. 15 No 2, Pp 178 - 198.
[2] Obadan, M. I 2004; " Globalisation And Economic Management In Africa " Chapter One In: Nigeria Economic Society Paper For The 2003 Annual Conferences (Ibadan Nigeria Economic Society).

[3] Kiyota, K. And Shujiro, U. 2004; Exchange Rate, Exchange Rate Volatility And Foreign Direct Investment. The World Economy, Vol, 27 Issue 10, Pp 1501 - 1536.

[4] World Bank 1994; Nigeria Structured Adjustment Programme. Policies Implementation And Impact. World Bank Report No: 130534Jni.

[5] World Bank 2003; Financial Flows And Developing Countries. A World Bank Business Quarterly Report.

[6] Aseidu, G. 2001; On The Determinant Of Foreign Direct Investment To Developing Countries. Is African Really Different? World Development 30(1) Pp 7 - 19.

[7] Cushman, D. O 1998; Exchange Rate Certainty And Foreign Direct Investment In The United State. Wethwirtschafilies Archive 124:2 Pp 297 - 308.

[8] Goldberg, Linda And Charles Kolstad. 1993; Foreign Direct Investment, Exchange Rate Variability And Demand Uncertainty. International Economic Review. Vol. 36 No 4 Pp $65-73$.

[9] Ogunleye 2008; Exchange Rate Volatility And Foreign Direct Investment Inflows In Selected Sub-Saharan African Countries. Phd Dissertation. University Of Ibadan.

[10] Simeon Oke, O. O. 2005; Exchange Rate And Industrial Performance In Nigeria. Journal Of Economics And Social Studies. Vol. 16, 2009.

[11] Takaendesa, P. 2006; The Behaviour And Fundamental Determinants Of Real Exchange Rate In South Africa. A Masters Thesis Submitted To Rhodes University, South Africa.

[12] Omoniyi, B. B. And Omobitan, O. A. 2011; The Impact Of Foreign Direct Investment On Economic Growth In Nigeria. International Research Journal Of Finance And Economics, London.

[13] FDI Magazine 2003 http/www.Fdiintlligence.com.

[14] Johansen, S., 1988. Statistical analysis of cointegration vectors. J. Econ. Dyn. Control, 12: 231-254.

[15] Olayiwola, K. and H. Okodua, 2009. Foreign direct investment, non-oil export and economic growth in Nigeria: A causality analysis. Proceeding for the $14{ }^{\text {thr }}$ Annual Conference on Econometric Modelling for Africa, for the African Econometric Society, Abuja 8-10 July.

[16] Chuku, A.C. (2010). Monetary and Fiscal Policy Interactions In $\quad$ Nigeria: An Application of a State Space Model With MarkovSwitching. CBN Journal of Applied Statistics, Vol. 1, No. 1, (Dec.).

[17] Anyanwu, J. C. et al. (1997). The Structure of the Nigerian Economy (1960-1997). Onitsha: JOANEE Educational Publishers.

[18] Ekpo, A. H. (2012). Employment, Growth and Poverty Reduction in an Oil Export Economy: Evidence from Nigeria, being paper presented at the 53rd Annual Conference of the Nigerian Economic Society, 27-30 August, Nicon Luxury Hotel, Abuja. 
[19] Federal Republic of Nigeria. (2007). Vision 20-2020 Blueprint.

[20] F.Allen and D.Gale, "Competition and financial stability,"Journal of Money, Credit, and Banking pp. 433-480, 2004.

[21] E.Kocenda and J. Valachy, "Exchange rate volatility and regime change: A visegrad comparison" Journal of Comparative Economics, pp. 727-753, 2006.

[22] A.C. Arize, T. Osang, and D.J. Slottje, "Exchange rate volatility and foreign trade: Evidence from thirteen LDCs" Journal of Business and Economics Statistics, pp. 10-17, 2000.

[23] K.L.Wang and C.B. Barrett," Estimating the Effects of Exchange Rate Volatility on Export Volumes" Journal of Agricultural and Resource Economics,pp.225-255,2007.

[24] C.Sauer and A.K.Bohara," Exchange rate volatility and exports: Regional differences between developing and industrialized countries," Review of International Economics, 2001.
[25] G.Corsetti, P.Pesenti, and N.Roubini, "What caused the asian currency and financial crisis?" Japan and the World Economy, pp.305-373, 1999.

[26] A.J. Makin“ International economics, finance and trade," The Balance of Payments and the Exchange Rate,vol. I, 2004.

[27] S. Tenreyro," On the trade impact of nominal exchange rate volatility," Journal of Development Economics, pp. 485-508, 2007.

[28] A.R.Ghosh, A.M.Gulde, andH.C.Wolf, Exchange Rate Regimes: Choices and Consequences, The MIT Press, 2003.

[29] H.Duncan, “ The effect of exchange rate volatility on trade and employment: A brief review of the literature economics" Macroeconomy, Economic Bias andEmployment, vol. 28, no. 3 , pp $133-152,2001$. 